\title{
TARTU RADIOCARBON DATES I
}

\author{
A. LIIVA, E. ILVES, and J. M. PUNNING \\ Institute of Zoology and Botany, Academy of Sciences \\ Estonian S.S.R.
}

Preparations for the development of a laboratory for the determination of absolute age by the radiocarbon method were started at the Geobiochemical Laboratory of the Institute of Zoology and Botany of the Academy of Sciences of the Estonian SSR in 1957. Dating of various carbon-containing specimens has been carried out since 1959 .

The measurement of natural $\mathrm{C}^{14}$ activity is performed by a liquid scintillation method. Methanol and benzene have been used as the carriers of natural $\mathrm{C}^{14}$ activity, the former for samples from TA-I to TA-55, the latter for specimens beginning with TA-56.

Methanol has been synthesized by the method of Pringle (Pringle et al., 1955) by the reduction of $\mathrm{CO}_{2}$ with lithium aluminium hydride yielding lithium aluminium methylate from which methanol is isolated after alkoholysis. The average yield of the synthesis has been $50 \%$ as calculated on the basis of $\mathrm{CO}_{2}$ (Liiva and Ilves, 1962) .

The synthesis of benzene (Starik et al., 1963) is carried out through lithium carbide or calcium carbide with their subsequent break-down with water and with the trimerization of acetylene obtained by means of the Ziegler catalyst (iso- $\left.\mathrm{C}_{4} \mathrm{H}_{9}\right)_{3} \mathrm{Al}-\mathrm{TiCl}_{4}-$ into benzene. The yield of benzene from acetylene has amounted to $55 \%$ (Punning et al., 1966).

Counting of natural $\mathrm{C}^{14}$ is performed with the help of a one-channel scintillation device (Liiva and Ilves, 1963a). In the device the following specially selected photomultiplier tubes (FEU) have been used: FEU-13, FEU-42; FEU-43, EMI 9067 (Liiva et al., 1966).

The cells for the liquid scintillator have been constructed by us and were made from aluminium with a potasium-free glass window (Liiva and Ilves, 1963b).

A layer of lead with a thickness of $12 \mathrm{~cm}$ and one of mercury, 2.5 $\mathrm{cm}$ thick, have been used for protection from cosmic radiation and from external radioactivity.

Automatic registration of counts is carried out by means of a numerical impulse-recorder device (Punning et al., 1966).

Wood dating from A.D. $1850 \pm 10 \mathrm{yr}$ has been used as a reference standard of modern carbon. Old-carbon preparation has been synthesized from anthracite.

For methanol $(70 \mathrm{ml}$ of a scintillator solution containing $15 \%$ of $\mathrm{CH}_{3} \mathrm{OH}$ by volume) the rate of the background has been $6.02 \pm 0.06$ counts/min, the pure count of modern carbon being $9.02 \pm 0.12$ counts/ min. The maximum determinable age is equal to 28,200 yr ( 48 hours counting $4 \sigma$ criterion). When benzene (25 $\mathrm{ml}$ of a scintillator solution containing $40 \%$ of $\mathrm{C}_{6} \mathrm{H}_{6}$ by volume) has been used, the corresponding 
values have been $5.26 \pm 0.085$ counts $/ \mathrm{min}, 54.73 \pm 0.17$ counts $/ \mathrm{min}$ and 43,600 yr.

All radiocarbon clata have been calculated proceeding from the period of the half-life of $\mathrm{C}^{14}$ equal to $5568 \pm 30$ yr. All dates are calculated from the year 1950 .

\section{Kääpa series}

ARCHAEOLOGIC SAMPLES

Neolithic settlement Kääpa is located in Võru District of Estonian SSR on Võhandu River $8 \mathrm{~km}$ NE of town Võru. Cultural layer up to 50 $\mathrm{cm}$ thick lies in lower part of peat deposit at depth up to $210 \mathrm{~cm}$ from bottom surface and penetrates in places into sandy loam layer underlying peat (Liiva, 1963). Oldest part of cultural layer contains ceramic materials of Narva type archaeologically dated first half or middle of third millennium B.c. (Liiva et al., 1955). In uppermost horizon of cultural layer were found pitted-comb ceramics. Pollen analyses (by A. Sarv) indicate the settlement existed at end of Atlantic period, i.e., Pollen Zone IV (V. Post-Nilsson system).

\section{TA.4. Kääpa}

$4350 \pm 220$

Charred wood from cultural layer of settlement Kääpa. Sample coll. 1959 by A. Liiva and subm. by L. Jaanits, Inst. of Hist., Acad. Sci. of Estonian SSR (later referred to as Inst. of Hist.).

\section{TA.5. Kääpa}

$4865 \pm 235$

Peat from lower part of cultural layer of settlement Kääpa. Coll. 1959 by A. Liiva; subm. by L. Jaanits.

\section{TA-6. Kääра}

$4480 \pm 255$

Elk bone from cultural layer of settlement Kääpa. Coll. 1959 by L. Jaanits: subm. by K. Paaver, Inst. of Zool. \& Bot., Acad. Sci. of Estonian SSR.

\section{Narva series}

Multi-layered settlement of Stone age on territory of town Narva. Probable age: Mesolithic layer I, 4th millennium в.c.; Mesolithic layers II and III, about the age of settlement Kunda (eighth to sixth millennium B.C.) (Liiva, et al., 1965; Jaanits, 1959).

\section{TA-7. Narva}

$5300 \pm 250$

Charcoal from Mesolithic layer I of settlement Narva. Coll. 1960 by A. Liiva; subm. by L. Jaanits. 
TA-33. Narva

$\mathbf{3 8 7 0}$ B.c.

Charcoal from a hearth of settlement Narva. Samples located at depth of 90 to $110 \mathrm{~cm}$. Coll. 1960 and subm. by L. Jaanits.

TA-17. Narva

$6020 \pm 120$

Bones from Mesolithic layer II of settlement Narva. Coll. 1960 and subm. by L. Jaanits.

TA-40. Narva

$6740 \pm 250$

4790 в.C.

Charcoal from under a hearth of Mesolithic layer II. Coll. 1963 by A. Liiva and E. Ilves; subm. by L. Jaanits.

\section{TA-52. Narva}

$7315 \pm 190$

5365 B.C.

Charcoal from lower part of Mesolithic layer II at depth of 212 to $217 \mathrm{~cm}$. Coll. 1964 by E. Ilves; subm. by L. Jaanits.

TA-41. Narva

$7090 \pm 230$

5140 B.c.

Charcoal from Mesolithic layer III at depth of 300 to $310 \mathrm{~cm}$. Coll. 1963 by A. Liiva and E. Ilves; subm. by L. Jaanits.

TA-25. Narva

$7580 \pm 300$

Charcoal from Mesolithic layer III at depth of 223 to $212 \mathrm{~cm}$. Coll. 1962 by E. Ilves; subm. by L. Jaanits.

TA-53. Narva

$7640 \pm 180$

Charcoal from Mesolithic layer III at depth of 313 to $318 \mathrm{~cm}$. Coll. 1964 and subm. by L. Jaanits.

\section{Kunda series}

Samples from settlement Kunda-Lammasmägi, Rakvere District, Estonian SSR, $4 \mathrm{~km} \mathrm{~S}$ of town Kunda. Cultural layer lies on ground moraine at depth up to $62 \mathrm{~cm}$ and is covered with thin sterile interbed of clay (Liiva et al., 1965). Pollen analyses showed that Mesolithic settlement existed in second half of Boreal climatic period. Coll. 1961 by A. Liiva; subm. by L. Jaanits.

\section{TA-14. Kunda}

$\mathbf{8 3 4 0}=\mathbf{2 8 0}$

Charcoal from lower horizon of Mesolithic layer.

\section{TA-16. Kunda}

$6015 \pm 210$

4065 B.c.

Elk bones from upper horizon of cultural layer. The given layer was not in its original position because in it were discovered finds of 
Mesolithic as well as non-Neolithic origin, including pitted-comb ceramics. Coll. 1961 and subm. by K. Paaver, Inst. of Zool. and Bot. Comment: sampie may be attributed to late stage of Mesolithic settlement, or the bone may have been soiled by modern carbon.

\section{TA-12. Kunda}

$9780 \pm 260$ 7830 B.C.

Mammoth tusk from settlement. Coll. 1936 by R. Indreko; subm. by K. Paaver. Comment: dating of sample and of lower cultural layer (TA14) confirmed that the bone does not belong to the period of the existence of camp site but to an earlier date.

\section{TA-8. Kreichi}

$4020 \pm 300$

2070 B.c.

Wood from Neolithic settlement Kreichi, Ludze District, Latvian SSR. Pitted-comb ceramics and, in a small quantity, textile ceramics were discovered on territory of camp site (Zagorskij, 1960). Probable age of sample, bcginning of 2nd millennium в.c. Coll. 1959 by F. Zagorskij; subm. by K. Paaver.

\section{TA-10. Tamula, pile}

$3600 \pm 180$

Wood (constr. pile) from Late Neolithic settlement Tamula, near town Võru, Estonian SSR. Cultural layer, 30 to $40 \mathrm{~cm}$ thick, is located in peat deposit at depth of 20 to $60 \mathrm{~cm}$ from ground surface. The pile was located in grass peat of underlying cultural layer so that its upper end reached the lower horizon of cultural layer, its tapering end penetrating into lake marl. Pitted-comb ceramic materials were found in cultural layer and cord ceramics in upper layers (Jaanits, 1954). Pollen analysis data (by A. Sarv) attribute the settlement to the Sub-Boreal period, Pollen Zone III (V. Post-Nilsson system). Probable age, first half of second millennium в.C. (Jaanits, 1959). Coll. 1956 and subm. by L. Jaanits.

\section{TA-28. Tamula, elk}

$4050 \pm 180$

Elk bones from cultural layer of Late Neolithic settlement Tamula. (See TA-10.) The sample evidently dates back to early period of the existence of settlement. Coll. 1961 and subm. by K. Paaver.

TA-11. Loona

Modern

Bovine bone found on territory of Late Neolithic settlement at Loona, Kingissepa District, Estonian SSR, $3 \mathrm{~km}$ SW of contemporary settlement Kihelkonna. Cultural layer, 30 to $40 \mathrm{~cm}$ thick, lies immediately under turf cover. Archaeologic date of the existence of camp site is first half of second millennium B.C. Coll. by L. Jaanits; subm. by K. Paaver. Comment: analysis proved that the dated find got into Neolithic layer from later horizons. 


\section{TA-20. Villa}

$3570 \pm 240$

1620 B.c.

Elk bones from lower part of cultural layer of Late Neolithic settlement Villa, Võru District, Estonian SSR, $3 \mathrm{~km} \mathrm{NE}$ of town Võru. Cultural layer with thickness of 50 to $70 \mathrm{~cm}$ lies on clay in peat deposit (Jaanits, 1959). Heterogenous materials (pitted comb as well as cord ceramics along with ceramics of early Metal Age) were found in settlement. Coll. 1951 and subm. by K. Paaver. Comment: dating showed that samples goes back to period of existence of settlement.

\section{TA-21. Rõuge}

$1190 \pm 230$

A.D. 760

Charred coal from burnt-out layer I and II of $\mathrm{E}$ wall of settlement Rõuge, Võru District, Estonian SSR, $17 \mathrm{~km}$ SW of town Võru. Sample lay at depth of 68 to $70 \mathrm{~cm}$ from ground surface. Probable age, 6th to llth century A.D. (Schmiedehelm, 1959). Coll. 1959 and subm. by M. Schmiedehelm, Inst. of Hist.

\section{TA-23. Leimanishki, wood}

$3970 \pm 250$

2020 B.c.

Charred wood from Late Neolithic settlement Leimanishki, Rezekne District, Latvian SSR. The finds were discovered in unconsolidated layer of peat and sand beneath black peat deposit. At depth of 180 to $200 \mathrm{~cm}$ there lies a layer of bluish clay. Sample was taken from depth of 100 to $105 \mathrm{~cm}$ where cord ceramic materials were discovered in thin layer, partly mixed with textile ceramics. Presumable archaeological age, first half or middle of 2nd millennium B.c. (Vankina, 1962). Coll. 1961 by L. Vankina; subm. by A. Dukkur, Mus. of Hist. of Latvian SSR.

\section{TA-27. Leimanishki, bones}

$3770 \pm 200$

1820 B.c.

Bones from Late Neolithic settlement Leimanishki (see TA-23).

\section{TA-24. Sarnate, charcoal}

$4490 \pm 250$

2540 B.C.

Charcoal from a hearth of Neolithic settlement Sarnate, Ventspils District, Latvian SSR $(0.75 \mathrm{~km} \mathrm{E}$ of settlement Sarnate).

In the cultural layer were found pitted-comb as well as textile ceramics along with ceramics characteristic of settlement Sarnate, having several characteristics common with ceramics of Narva type. Presumable age of settlement, 2nd half of third millennium to middle of 2nd millennium B.c. (Vankina, 1960). On the basis of pollen analyses (by A. Sarv) the settlement may be attributed to Sub-Boreal period. Coll. 1958 by L. Vankina; subm. by A. Dukkur.

\section{TA-26. Sarnate, bones}

$4700 \pm 250$

Bones from Neolithic settlement Sarnate (see TA-24). 


\section{TA-35. Sulgu}

Charcoal from settlement Sulgu V “a”, Pryazhensk District, Karelian ASSR, located on left bank of Sulgu River at $1.5 \mathrm{~km}$ from settlement Kudoma. Sample was taken from a hearth and lay at 30 to $80 \mathrm{~cm}$ from ground surface. Presumable archaeological age, end of third, beginning of second millennium B.c. (stone implements of Neolithic types, ceramics of "Sperrings" type and of pitted-comb Volga-Oka type). Coll. 1960 and subm. by G. A. Pankrushev, Inst. of Linguistics, Literature and History, the Karelian branch of Acad. Sci. of SSSR. Comment: dating of the same settlement (carried out at the Lab. of the Inst. of Archeol., Acad. Sci. SSSR) dated its age at $1960 \pm 150 \mathrm{yr}$. Note added in proof: Recent studies (private commun., G. A. Pankrushev) have revealed that settlement Sulgu also contains ceramic materials attributed to early Iron Age; the latter corresponds with the radiocarbon measurements.

\section{TA-38. Siimusaare \\ $2370 \pm 210$ \\ 420 B.C.}

Charcoal from hearth in lower part of cultural layer of settlement Siimusaare, Viljandi District, Estonian SSR, $1 \mathrm{~km} \mathrm{~N}$ of settlement Meleski. Upper part of cultural layer starts immediately beneath ploughedup turf (at $25 \mathrm{~cm}$ ) and is attributed to early period of Iron Age (striated and textile ceramic materials). Lower part of cultural layer (not containing any ceramic materials) is attributed to the Mesolithic. Sample was picked at depth of 50 to $95 \mathrm{~cm}$ from ground surface and is dated at early period of the existence of settlement. Coll. and subm. 1965 by H. Moora, Viljandi Interdistrict Mus. of Regional Studies.

\section{TA-47. Mt. Amiranis}

$3215 \pm 170$

1265 B.C.

Fragments of human skeleton from burial place of settlement Mt. Amiranis (Akhaltsikh District, Georgian SSR, $2.5 \mathrm{~km}$ NE of town Akhaltsikh on left bank of Potskhovi River.) Probable date, 3rd millennium B.C. (Tchubinishvili, 1963). Coll. 1963 by Meskhety-Dzhavakhety archaeological expedition; subm. by Inst. of Hist. of Georgian SSR.

\section{TA-72. Lommi}

Modern

Charcoal from Neolithic settlement Lommi in NW part of Leningrad Region on Noiki River (small left tributary of Luga River) 3 to 4 $\mathrm{km} \mathrm{W}$ of village Pulkovo. Cultural layer, up to $1 \mathrm{~m}$ thick, starts almost at ground surface and is covered only by thin alluvial sand layer. In places cultural layer proved to be ploughed up (Gurina, 1961; Jaanits, 1959). Sample coll. from a hearth, 47 to $72 \mathrm{~cm}$ from ground surface. Probable archaeological date of camp site, end of 3rd millennium or first half of 2nd millennium B.c. (characterized by typical pitted-comb ceramics). Coll. 1940 by R. Indreko; subm. by L. Jaanits. 


\section{TA-73. Padise}

$630 \pm 100$

Charred wood from part of $\mathrm{E}$ wall of settlement Padise in Harju District, Estonian SSR. Depth of sample, $225 \mathrm{~cm}$. Presumable archaeological age 700 or 1500 yr. Coll. 1964 and subm. by O. Saadre, Inst. of History.

GEOLOGIC SAMPLES

$$
3310 \pm 230
$$

\section{TA-3. Sõjamäe}

1360 B.C.

Wood from boundary (recurrence) horizon of peat bog Sõjamäe, Harju District, Estonian SSR, 3 to $5 \mathrm{~km} \mathrm{E}$ of Tallinn. Relative age, transition from Sub-Boreal to Sub-Atlantic period. Subm. by Prof. K. Orviku, Inst. of Geol., Acad. Sci. of Estonian SSR (later referred to as Inst. of Geol.).

\section{TA-19. Kaali}

$$
2530 \pm 130
$$

Charcoal picked at depth of 120 to $130 \mathrm{~cm}$ from the fill of meteoritic crater No. 2 at Kaali, Is. Saaremaa, Kingissepa District, Estonian SSR. Putative geological age of the fall of meteorite, 3000 to $4000 \mathrm{yr}$ ago. Coll. 1961 by A. Aloe; subm. by K. Orviku, Inst. of Geol.

\section{TA-22. Kaali}

Charcoal from meteoritic crater No. 2 at Kaali (see TA-19), collected at depth of 50 to $150 \mathrm{~cm}$. Coll. 1962 by A. Aaloe and E. Ilves; subm. by K. Orviku.

\section{TA-29. Pihlasoo}

$$
3280 \pm 180
$$

Sedge and reed peat from bog Pihlasso, Is. Hiiumaa, Estonian SSR. Sample taken at depth of 505 to $515 \mathrm{~cm}$. Structure of section down to $300 \mathrm{~cm}$, upper peat; 300 to $350 \mathrm{~cm}$, transitional peat; 350 to $400 \mathrm{~cm}$, lower peat with admixture of wood; 400 to $515 \mathrm{~cm}$, lower arboreal peat, sand (marine bed). Pollen analyses attribute sample to upper part of Pollen Zone III (V. Post-Nilsson system). Coll. 1962 and pollen-analyzed by H. Kessel (Rebassoo, 1964); subm. by L. Laasimer, Inst. of Zool. and Bot.

\section{Ulila series}

Peat-bog Ulila is located in Võrtsjärve depression where in Early Holocene and extensive reservoir named Suur-Võrtsjärv was formed. Thickness of peat is $280 \mathrm{~cm}$; beneath peat lies lacustrine marl (depth 280 to $480 \mathrm{~cm}$ ). Valves of shells are met with in paleolacustrine sediments. Pollen analyses attribute shell sample to early part of Pollen Zone III (V. Post-Nilsson system). Pollen diagram was prepared by E. Liivrand and R. Pirrus. Coll. 1962 by M. Punning; subm. by K. Kajak, 
State Production Geol. Comm., Estonian SSR (later referred to as Geol. Comm.).

TA-30. Ulila

$6270 \pm 240$

4320 в.c.

Arboreal and reed peat collected at depth of 260 to $280 \mathrm{~cm}$. Sample overlay lacustrine marl and is attributed to Pollen Zone VI.

\section{TA-31. Ulila}

$7800 \pm 260$

5850 в.C.

Lacustrine marl taken at depth of 280 to $300 \mathrm{~cm}$. Sample lay immediately beneath peat. It is referred to Pollen Zone VII.

\section{TA-32. Ulila}

$9760 \pm 320$

7810 B.C.

Lacustrine marl picked at depth of 460 to $480 \mathrm{~cm}$. Sample is attributed to the beginning of accumulation of lacustrine marl. Probable age 7700 to $9800 \mathrm{yr}$.

TA-36. Kaagvere, $400 \mathrm{~cm}$

$>30,000$

Sandy loam with plant remains collected at depth of $400 \mathrm{~cm}$ near town Otepää in Valga District, Estonian SSR. Interstadial deposit of Valdai stage, 330 to $420 \mathrm{~cm}$ thick. Coll. 1963 and subm. by K. Kajak.

\section{TA-50. Kaagvere, 346-362 $\mathrm{cm}$}

$15,150 \pm 575$

13,200 в.C.

Sandy loam with plant remains collected at depth of 346 to $362 \mathrm{~cm}$, overlying TA-36. From intermoraine deposits lying at depth of 320 to $370 \mathrm{~cm}$. Pollen analyses showed spectra of pine and birch pollen. Pollen of herbaceous plants and spores shows cold-loving character. Coll. 1963 and subm. by K. Kajak.

\section{TA-43. Kuliska, peat}

$8525 \pm 250$

Peat from bog Kuliska, located in depression of Lake Pskov in Pskov Region. Peat layer, $570 \mathrm{~cm}$ thick, consists of arboreal, sedge and reed peat. Depth of sample 550 to $570 \mathrm{~cm}$. Sample is attributed to Pollen Zone VIII (V. Post-Nilsson system). Pollen diagram was produced by M. Grigorovitch. Coll. 1963 and subm. by V. Paulman, Geol. Comm.

\section{TA-43A. Kuliska, humic substance}

$8530 \pm 300$

\section{B.c.}

Same as TA-43, repeated with aim of studying contamination of sample. Dating was carried out by means of extracted humic substances.

\section{TA-47. Kuliska, marl}

$10,400 \pm 350$

8450 B.C.

Silty lacustrine marl from bog Kuliska. (See TA-43.) Thickness of layer $20 \mathrm{~cm}$. Depth of sample 550 to $570 \mathrm{~cm}$. Sample is attributed to Pollen Zone IX (V. Post-Nilsson system) . Coll. 1963 and subm. by V. Paulman. 
TA-45. Rõngu, 600-670 $\mathrm{cm}$

Peaty sapropelite with plant remains, near settlement Rõngu in Tartu District, Estonian SSR. Peat is overlain by brown sandy loam, mixed with gravel and pebbles (at 30 to $110 \mathrm{~cm}$ ), sand (at 110 to $230 \mathrm{~cm}$ ) and silty loam with plant remains (at 230 to $250 \mathrm{~cm}$ ). Depth of sample 600 to $670 \mathrm{~cm}$. Coll. 1964 and subm. by K. Kajak.

TA-46. Rõngu, 670-720 $\mathrm{cm}$

$>\mathbf{3 0 , 0 0 0}$

Sapropelite, dark-grey, with plant remains, near settlement Rõngu. (See TA-45.) Sapropelite layer, $110 \mathrm{~cm}$ thick, is underlain by calcareous sapropelite with admixture of sand and plant remains (at 730 to 765 $\mathrm{cm}$ ), and lower by sand. Depth of sample 670 to $720 \mathrm{~cm}$. Coll. 1964 and subm. by K. Kajak.

TA-49. Yakutia

$3005 \pm 175$

1055 B.C.

Wood from the valley of Mandychen River in Yakutian ASSR. Depth of sample 87 to $97 \mathrm{~cm}$, in peat layer interbedded between layers of varved clay above perpetually frozen ground. Aim of dating was to establish the time of the melting of the glacier which gave rise to the valley of Mandychen River and to determine the time of the formation of lakes. Coll. 1963 and subm. by A. Tamme and M. Rubel, Inst. of Geol.

\section{TA-54. Rannametsa}

$7860 \pm 190$ 5910 B.c.

Wood buried in peat from Pärnu District, Estonian SSR. Depth of sample 497 to $503 \mathrm{~cm}$. Peat is underlain by deposit of lake Ancylus and overlain by pelitic lagoon sediments with remains of skeletons. Coll. 1959 and pollen-analyzed by H. Kessel (1963); subm. by K. Orviku, Inst. of Geol.

TA-55. Sindi

$6710 \pm 170$

4760 B.C.

Wood, buried in peat, collected in Pärnu District, Estonian SSR. Sample lay at 195 to $202 \mathrm{~cm}$, sedge and reed peat at 170 to $248 \mathrm{~cm}$. Peat is underlain by fine-grained sediments of Lake Ancylus, overlain by coastal sediments. Coll. 1959 and pollen-analyzed by H. Kessel (1963); subm. by K. Orviku.

\section{TA-57. Kurenurme}

$12,650 \pm 500$ 10,700 B.c.

Submorainic arboreal remains (willow) from Kurenurme in Võru District, Estonian SSR. From intermorainic sediments (Bölling interval). Depth of sample $580 \mathrm{~cm}$. Coll. 1963 and subm. by K. Kajak.

\section{TA-59. Kahala}

$8595 \pm 75$

6645 B.C.

Buried peat of Ancylus age, from Harju District, Estonian SSR Depth of sample 115 to $145 \mathrm{~cm}$. Probable age 9000 to $8000 \mathrm{yr}$. Pollen 
diagram was produced by H. Kessel. Sample belongs to Pollen Zone IX (V. Post-Nilsson system). Coll. 1965 and sum. by K. Elterman, Geol. Comm.

TA-60. Kivijärve $7590 \pm 75$

Well-disintegrated peat from bog Kivijärve in Harju District, Estonian SSR. Depth of sample 640 to $670 \mathrm{~cm}$. Coll. 1965 and subm. by $\mathrm{K}$. Elterman.

TA-61. Hara

$7080 \pm 75$

Lacustrine sapropelite and peat from bog Hara in Harju District, Estonian SSR. Depth of sample 500 to $530 \mathrm{~cm}$. Pollen diagram was produced by H. Kessel. Sample belongs to Pollen Zone V-VI (V. Post-Nilsson system). Coll. and subm. by K. Elterman.

\section{TA-62. Aravete}

$$
7880 \pm 70
$$

Peat from bog Aravete in Paide District, Estonian SSR. Depth of sample 350 to $400 \mathrm{~cm}$. Pollen diagram was produced by E. Valt. Sample is attributed to Pollen Zone VIII (V. Post-Nilsson system). Coll. 1965 and subm. by K. Elterman.

\section{TA-63. Peedu}

$20,673 \pm 100$

Submorainic peat from settlement Peedu in Tartu District, Estonian SSR. Sample was taken at depth of 668 to $677 \mathrm{~cm}$. Coll. and subm. by K. Kajak.

\section{Kuiksilla series}

Peat bog Kuiksilla is located in S Estonia, Valga District, Estonian SSR. Low-lying deposit of peat with average thickness of $3 \mathrm{~m}$ rests on clay. Samples were taken from wall of cleared pit. Structure of the section: 0 to $25 \mathrm{~cm}$, arboreal and sedge peat, degree of composition $70_{\%}^{\circ}$; 25 to $120 \mathrm{~cm}$, reed peat, degree of decomposition $35-40 \%$; 120 to $170 \mathrm{~cm}$, arboreal and reed peat, degree of decomposition $40 \% ; 170$ to $315 \mathrm{~cm}$, reed peat, degree of decomposition $30-35 \% ; 315$ to $325 \mathrm{~cm}$, reed and Bryales peat, degree of decomposition $40 \%$; 325 to $330 \mathrm{~cm}$, reed sapropelite; $330 \mathrm{~cm}$, clay enriched in upper part by organic matter. Coll. 1964 by E. Ilves; pollen-analyzed (V. Post-Nilsson system) by R. Männil, H. Kessel, R. Pirrus, E. Valt, Inst. of Geol.

\section{TA-64. Kuiksilla}

$4560 \pm 80$

Reed peat, depth 102.5 to $107.5 \mathrm{~cm}$. Boundary between Pollen Zones IV and III. 


\section{TA-65. Kuiksilla}

Arboreal and reed peat, depth 127.5 to $132.5 \mathrm{~cm}$. Maximum of oak. Pollen Zone IV.

TA-66. Kuiksilla

$\mathbf{5 8 0 0} \pm \mathbf{7 0}$

3850 B.C.

Arboreal and reed peat, lepth 157.5 to $162.5 \mathrm{~cm}$. Maximum of elm. Pollen Zone V.

TA-67. Kuiksilla

$6645 \pm 70$

4695 B.c.

Reed peat, depth 177.5 to $182.5 \mathrm{~cm}$. Boundary between Pollen Zones VII and VI.

TA-68. Kuiksilla

$7785 \pm 70$

Reed peat, depth 212.5 to $217.5 \mathrm{~cm}$. Boundary between Pollen Zones VIII and VII.

TA-69. Kuiksilla

$8095 \pm 75$

6145 B.C. VIII.

Reed peat, depth 247.5 to $252.5 \mathrm{~cm}$. Maximum of pine. Pollen Zone

TA-70. Kuiksilla

$9080 \pm 100$

7130 B.C.

Reed and Bryales peat, depth 315 to $319 \mathrm{~cm}$. Boundary between Pollen Zones IX and VIII.

\section{TA-71. Kuiksilla}

Peat sapropel, depth 329.5 to $334.5 \mathrm{~cm}$. Pollen Zone IX.

\section{REFERENCES}

Aaloe, A., 1960, Meteoric craters of Kaali: Looduskaitse teatmik (reference book on nature conservation), Tallinn (in Estonian).

Aaloe, A., Liiva, A., Ilves, E., 1963, The age of the meteoric craters at Kaali: Eesti Loodus, 5, p. 262-265 (in Estonian).

Indreko, R., 1948, Die mittlere Steinzeit in Estland. Mit einer Übersicht von Orviku, K. Über die Geologie des Kunda Sees: Kungl. Vitterhets Historie och Antikvites Akademiens Handlingar, Stockholm, 66.

Jaanits, L., 1954, Fresh data on the Neolithic in the Baltic countries: Sovetskaya arkhoologia, v. 30, p. 159-204 (in Russian) .

1959, Settlements of the Neolithic and the Early Metal Age at the estuary of the Emajõgi: Tallinn (in Estonian).

Kessel, H., 1963, Holocene coastal formations on the coast of south-west Estonia: Works of the Inst. of Geol., Acad. Sci. Estonian SSR, v. 12, p. 123-144 (in Russian).

Liiva, A., 1963, Radiocarbon dating of the Neolithic settlement at Kääpa: Proc. of Acad. Sci., Estonian SSR, v. 12. Series of Social Sciences, 1, p. 60-61 (in Estonian) .

Liiva, A., Ilves, E., 1962, Methanol synthesis for the determination of natural radiocarbon by a scintillation method: Proc. of Acad. Sci., Estonian SSR, v. 11. Series of physico-mathem. and technol. sciences, 4, p. 272-276 (in Russian).

1963a, On the work of the radiocarbon laboratory of the Institute of Zoology and Botany of the Acad. of Sci., Estonian SSR. Coll: Absolute Geochronology of the Quaternary Period, Moscow, p. 19-22 (in Russian). 
1963b, Metal counting bottles for liquid scintillation counters: Pribory i tekhnika eksperimenta, 5, p. 215-216 (in Russian).

Liiva, A. A., Ilves, E. O., Jaanits, L. J., 1965, Radiocarbon dating of some archeologic relics in the Baltic countries: Coll. Archeology and Natural Sciences, Moscow, p. 46-50 (in Russian).

Liiva, A., Ilves, E., Punning, J. M., in press, Energetic equivalent of some photomultiplier noises: Proc. of Acad. Sci., Estonian SSR. Series of physico-mathem. and technol. sciences (in Russian).

Pringle, R. W., Turchinetz, W., Funt, B. L., 1955, Liquid scintillation techniques for radiocarbon dating: Review of Sci. Instruments, v. 26, 9, p. 859-865.

Punning, J. M., Liiva, A., Ilves, E., in press, Development of the recording techniques of radiocarbon dating of absolute age: Proc. of Acad. Sci., Estonian SSR (in Russian).

Schmiedehelm, M. H., 1959, Settlement of Rõuge in SE Estonia: Works of the Joint Complex Expedition of the Baltic countries, Moscow, v. 1, p. 154-185 (in Russian).

Starik, L. E., Arslanov, H. A., Klener, I. R., 1963, Improved techniques of the chemical preparation of samples for radiocarbon dating by a scintillation method: Radiokhimia, v. 5, no. 2, p. 198-205 (in Russian).

Tchubnishvili, T., 1963, Mt. Amiranis Materials on the ancient history of MeskhetDzhavekheli: Tbilisi (in Georgian).

Vankina, L., 1960, Archeologic excavations in the settlement on the Sarnate peatbog in 1959: Theses of reports presented at the session devoted to the results of archeol. and ethnogr. expeditions of 1959, Riga, p. 30 (in Russian).

1962, Archeologic excavations in a settlement of the Late Neolithic on the banks of the Malta River near Leimanishki: Theses of the scientific session devoted to the results of archeol. and ethnogr. expeditions of 1961, Riga (in Russian).

Zagorskij, F., 1960, Neolithic settlement at Kreichi: Theses of reports presented at the session devoted to the results of archeol. and ethnogr. expeditions of 1959, Riga, p. 31 (in Russian). 